Proceeding Paper

\title{
Size Optimization of a Grid-Connected Solar-Wind Hybrid System in Net Zero Energy Buildings: A Case Study ${ }^{\dagger}$
}

\author{
Elaheh Sadeghi Bakhtiar ${ }^{1}$, Afshin Naeimi ${ }^{2}$, Ali Behbahaninia ${ }^{2}$ and Gloria Pignatta $^{3, *(D)}$ \\ 1 Department of Natural Resources and Environment, Science and Research Branch, Islamic Azad University, \\ Tehran 1477893855, Iran; e.sadeghi.bakhtiar@gmail.com \\ 2 Department of Energy System Engineering, Faculty of Mechanical Engineering, K. N. Toosi University of \\ Technology, Tehran 1969764499, Iran; anaeimi@alumni.kntu.ac.ir (A.N.); alibehbahaninia@kntu.ac.ir (A.B.) \\ 3 School of Built Environment, Faculty of Arts, Design, and Architecture, University of New South \\ Wales (UNSW), Sydney, NSW 2052, Australia \\ * Correspondence: g.pignatta@unsw.edu.au \\ $\dagger$ Presented at the 3rd Built Environment Research Forum, Sydney, Australia, 1 December 2021.
}

check for updates

Citation: Bakhtiar, E.S.; Naeimi, A.; Behbahaninia, A.; Pignatta, G. Size Optimization of a Grid-Connected Solar-Wind Hybrid System in Net Zero Energy Buildings: A Case Study. Environ. Sci. Proc. 2021, 12, 12. https://doi.org/10.3390/ environsciproc2021012012

Academic Editor: Khan

Rahmat Ullah

Published: 21 February 2022

Publisher's Note: MDPI stays neutral with regard to jurisdictional claims in published maps and institutional affiliations.

Copyright: (C) 2022 by the authors. Licensee MDPI, Basel, Switzerland. This article is an open access article distributed under the terms and conditions of the Creative Commons Attribution (CC BY) license (https:// creativecommons.org/licenses/by/ $4.0 /)$.

\begin{abstract}
This study proposes a hybrid renewable energy system consisting of photovoltaic panels and a wind turbine to supply the total or part of the demand of a grid-connected residential building and presents the optimal system size using a genetic algorithm. Wind speed, solar irradiance, and electricity demand are monitored in $15 \mathrm{~min}$ intervals over a year. It is found that the optimal values for PV panels' area, rated power of the wind turbine, and the tower height are $148.5 \mathrm{~m}^{2}, 1.5 \mathrm{~kW}$, and $20 \mathrm{~m}$, respectively. These optimal values lead to a total system cost of EUR 42,218 over 20 years.
\end{abstract}

Keywords: renewable energy; hybrid system; net-zero energy building; residential buildings; genetic algorithm

\section{Introduction}

A considerable part of the total energy in the world is consumed in the residential sector. Households represented 26\% of final energy consumption in Europe in 2019, most of which was supplied from fossil fuels [1]. Utilizing renewable energy such as wind, solar energy, and their hybridization instead of fossil fuels is a good option to supply electricity to buildings in urban and remote areas, which can operate in both grid-connected and standalone modes [2]. In this study, by finding the optimum size of a hybrid system consisting of a wind turbine (WT) and photovoltaic (PV) panels using a genetic algorithm (GA), the demand of a grid-connected building is provided.

Barakat et al. [3] introduced multi-objective optimization of a hybrid system by defining reliability, cost, and environmental aspects as objective functions. Ekren et al. [4] presented the optimum sizing of a wind-solar system using HOMER software, and Zhang et al. [5] proposed an integrated system that comprises hydropower, photovoltaic, and wind. Liu et al. [6] conducted a study on the optimal control technique of a hybrid system using power prediction. Das et al. [7] economically and environmentally investigated a PV/wind/diesel/battery-based hybrid system. Maleki et al. [8] optimized a hybrid solar-wind-hydrogen CHP system for residential applications. In addition, Dali et al. [9] performed an experimental study on a wind-solar system with battery storage that operates in grid-connected and standalone modes. Mikati et al. [10] illustrated the effect of the configuration of a small-scale hybrid wind-solar system on electricity network dependency. The innovation of this study is the use of actual wind speed, solar irradiance, and demand data of a net-zero energy building, which were measured in 15 min time steps throughout a year to make the study more realistic. 


\section{Materials and Methods}

The WT is of the horizontal axis type and is proper for home installations, and its capacity and tower height are decision variables of the GA. The power of the WT can be calculated using Equation (1) [11]:

$$
P_{w}= \begin{cases}\operatorname{Pr}_{r}\left(\frac{v^{3}}{v_{r}^{3}-v_{\text {cut,in }}^{3}}\right)-P_{r}\left(\frac{v_{\text {cut,in }}^{3}}{v_{r}^{3}-v_{\text {cut,in }}^{3}}\right) & , v_{\text {cut, in }} \leq \mathrm{v} \leq \mathrm{v}_{\mathrm{r}} \\ P_{r} & , v_{r} \leq \mathrm{v} \leq \mathrm{v}_{\text {cut,out }} \\ 0 & , \text { otherwise }\end{cases}
$$

where $\mathrm{P}_{\mathrm{r}}$ is rated power of the $\mathrm{WT}, \mathrm{v}_{\mathrm{r}}$ is rated wind speed, $\mathrm{v}_{\text {cut,in }}$ is the cut-in wind speed, and $v_{\text {cut,out }}$ is the cut-out wind speed. The PV panels are of the monocrystalline type and the area and the output power of a single PV panel are $1.65 \mathrm{~m}^{2}$ and $0.3 \mathrm{~kW}$, respectively. Additionally, the output power of the PV system can be defined using Equation (2) [12]:

$$
\mathrm{P}_{\mathrm{PV}}=\mathrm{n} \mathrm{A}_{\mathrm{C}} \eta \mathrm{I}_{\beta}
$$

where $\mathrm{n}$ is the number of PV panels, $A_{C}$ is the area of a single PV panel, and $\eta$ is its efficiency. $I_{\beta}$ is the irradiance on a surface with an inclination $\beta$ the computation method of which is given in [13]. The output power of the hybrid system is the sum of $P_{p v}$ and $P_{w}$. The self-consumption (SC) is the self-consumed hybrid system electricity $\left(\mathrm{E}_{\mathrm{lgc}}\right)$ divided by total electricity generation from the hybrid system. Moreover, the renewable fraction (RF) is the $\left(\mathrm{E}_{\mathrm{lgc}}\right)$ divided by the total demand [14]. The total cost of the system that is minimized using the optimization problem is defined as Equation (3) [11].

$$
\mathrm{TSC}=\mathrm{IC}+\mathrm{MC}+\mathrm{RC}-\sum_{\mathrm{x}=1}^{\mathrm{L}} \mathrm{C}_{\mathrm{x}} \frac{(1+\mathrm{i})^{\mathrm{x}-1}}{(1+\mathrm{d})^{\mathrm{x}}}
$$

where IC is the capital cost which comprises the total cost of purchasing WT, PVs, inverter, and controllers. $\mathrm{MC}, \mathrm{RC}, \mathrm{L}, \mathrm{C}_{\mathrm{x}}, \mathrm{i}$, and $\mathrm{d}$ are maintenance cost, replacement cost, system lifetime, revenue, inflation rate, and discount rate, respectively.

\section{The Case Study}

The case study in this research is a one-story residential building located in Granarolo dell'Emilia, Emilia-Romagna, Italy. It is a three-bedroom building with a total floor area of $118 \mathrm{~m}^{2}$ that was occupied by an elderly couple [15]. Figure 1 illustrates the hourly profile of average wind speed, solar irradiance, and electricity demand of the building over one year.
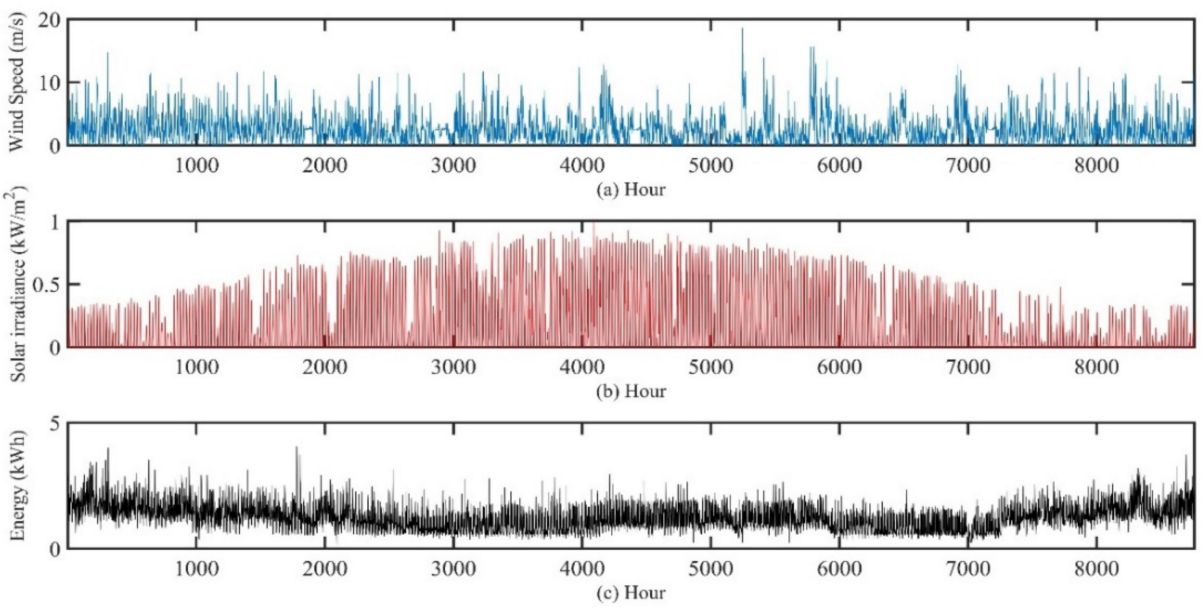

Figure 1. (a) Hourly profile of wind speed, (b) solar irradiance, and (c) electricity demand over one year. 
The lifetime of the hybrid system is assumed to be 20 years, and the lifetimes of the inverter and controllers are 10 and 5 years, respectively. Additionally, the total cost of maintenance is $2 \%$ of the initial cost $[16,17]$. The price of purchasing electricity from the grid and exporting it to the grid is $0.18 \mathrm{EUR} / \mathrm{kWh}$ and $0.06 \mathrm{EUR} / \mathrm{kWh}$, respectively [18]. Other technical and economic parameters of the component used in this research are given in Table 1.

Table 1. The technical and economic parameters of the hybrid system.

\begin{tabular}{|c|c|c|c|}
\hline Parameter & Unit & Value & Refs. \\
\hline PV capital cost & $\mathrm{EUR} / \mathrm{m}^{2}$ & 118.76 & {$[16,17]$} \\
\hline PV panel efficiency & $\%$ & 20 & {$[16,17]$} \\
\hline Ground albedo & $\%$ & 28 & {$[19,20]$} \\
\hline Tilt angle & o & 44.55 & [21] \\
\hline WT capital cost & EUR & $10,340 \times \mathrm{e}^{(0.1291 \times \operatorname{Pr})}$ & [22] \\
\hline Inverter capital cost & EUR & 1182 & {$[16,17]$} \\
\hline Inverter efficiency & $\%$ & 98 & [23] \\
\hline $\begin{array}{c}\text { PV controller capital } \\
\text { cost }\end{array}$ & EUR & 631.36 & {$[16,17]$} \\
\hline $\begin{array}{l}\text { PV controller } \\
\text { efficiency }\end{array}$ & $\%$ & 98 & {$[16,17]$} \\
\hline $\begin{array}{l}\text { WT controller capital } \\
\text { cost }\end{array}$ & EUR & 565.8 & {$[16,17]$} \\
\hline $\begin{array}{l}\text { WT controller } \\
\text { efficiency }\end{array}$ & $\%$ & 98 & {$[16,17]$} \\
\hline
\end{tabular}

\section{Results}

By implementing the genetic algorithm (GA) in MATLAB and minimizing Equation (3), the optimized area of PV panels, rated power of WT, and its tower height are obtained $148.5 \mathrm{~m}^{2}, 1.5 \mathrm{~kW}$, and $20 \mathrm{~m}$, respectively.

The capital cost is EUR 45,100, and the costs of maintenance and replacement over 20 years are EUR 13,548 and EUR 4077, respectively. Considering the total revenue of EUR 20,507 from exporting electricity to the grid, the total cost of the system (TSC) is EUR 42,218. The total monthly energy generated, consumed, imported, and exported and the demand are shown in Figure 2. About $94.4 \%$ of the total energy is generated by PVs and 5.6\% of that is by WT. In addition, it is found that PV panels, WT, inverter, and controllers account for $52.16 \%, 36.26 \%, 4.13 \%$, and $7.45 \%$ of the cost of the system, respectively.

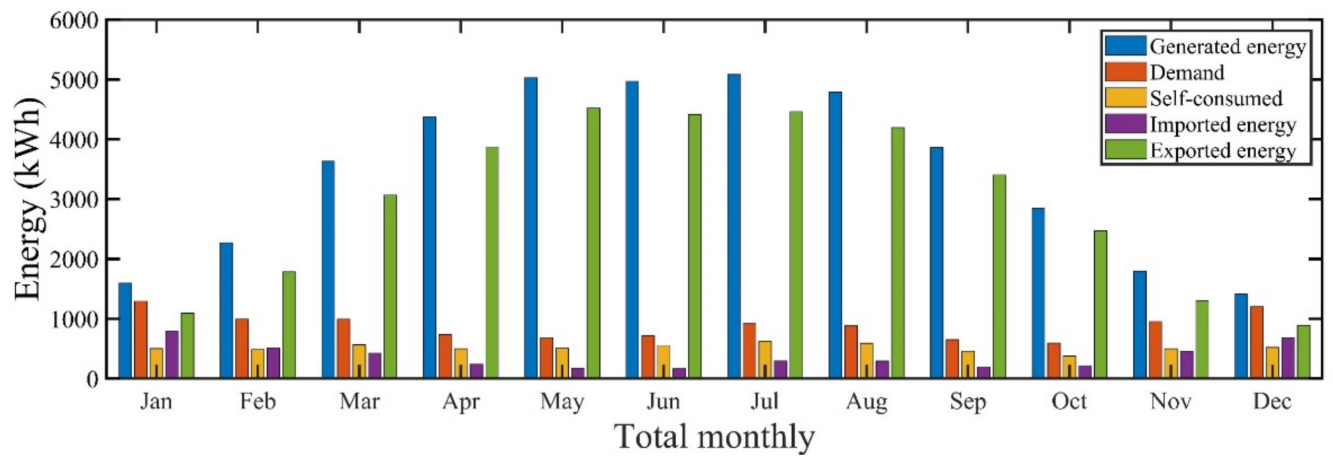

Figure 2. Total energy generated, demand, self-consumed hybrid system electricity, imported, and exported energy per month.

\section{Conclusions}

In this study, the optimal size of a solar-wind hybrid system in a grid-connected net-zero energy building was obtained by GA. By installing PV panels with an area of $148.5 \mathrm{~m}^{2}$ and a wind turbine with a rated power of $1.5 \mathrm{~kW}$ at a height of $20 \mathrm{~m}$, the total 
cost of the system, considering EUR 20,507 revenue from exporting electricity to the grid, is around EUR 42,000. It is observed that the low average wind speed in the case study is a reason to select the wind turbine with a low rated power by the GA. In addition, the self-consumption is about $15 \%$, and a considerable proportion of on-site generation is exported to the grid. The renewable fraction is approximately $58 \%$, which indicates the desirable performance of the hybrid system.

Author Contributions: Conceptualization: E.S.B., A.N., and G.P.; methodology: E.S.B., A.N., and A.B.; data curation: G.P.; writing-original draft preparation: E.S.B.; writing-review and editing: A.N. and G.P.; supervision: A.B. and G.P. All authors have read and agreed to the published version of the manuscript.

Funding: This research received no external funding.

Informed Consent Statement: Informed consent was obtained from all subjects involved in the study.

Acknowledgments: The authors would like to thank the building owners of the case study building for accepting to participate in this research and allowing the continuous monitoring campaign. Furthermore, sincere thanks to editors and anonymous reviewers for putting forward guiding measures to improve the quality of this paper.

Conflicts of Interest: The authors declare no conflict of interest.

\section{References}

1. Zhu, Z.; Lu, L.; Yao, X.; Zhang, W.; Liu, W. World Energy Balances Overview, 2020th ed.; Publications Office of the European Union: Luxembourg, 2020.

2. Jahangir, M.H.; Cheraghi, R. Economic and environmental assessment of solar-wind-biomass hybrid renewable energy system supplying rural settlement load. Sustain. Energy Technol. Assess. 2020, 42, 100895. [CrossRef]

3. Barakat, S.; Ibrahim, H.; Elbaset, A.A. Multi-objective optimization of grid-connected PV-wind hybrid system considering reliability, cost, and environmental aspects. Sustain. Cities Soc. 2020, 60, 102178. [CrossRef]

4. $\quad$ Ekren, O.; Canbaz, C.H.; Güvel, Ç.B. Sizing of a solar-wind hybrid electric vehicle charging station by using HOMER software. J. Clean. Prod. 2021, 279, 123615. [CrossRef]

5. Zhang, Y.; Lian, J.; Ma, C.; Yang, Y.; Pang, X.; Wang, L. Optimal sizing of the grid-connected hybrid system integrating hydropower, photovoltaic, and wind considering cascade reservoir connection and photovoltaic-wind complementarity. J. Clean. Prod. 2020, 274, 123100. [CrossRef]

6. Liu, S.; You, H.; Liu, Y.; Feng, W.; Fu, S. Research on optimal control strategy of wind-solar hybrid system based on power prediction. ISA Trans. 2021, in press. [CrossRef] [PubMed]

7. Das, B.K.; Alotaibi, M.A.; Das, P.; Islam, M.; Das, S.K.; Hossain, A. Feasibility and techno-economic analysis of stand-alone and grid-connected PV/Wind/Diesel/Batt hybrid energy system: A case study. Energy Strategy Rev. 2021, 37, 100673. [CrossRef]

8. Maleki, A.; Hafeznia, H.; Rosen, M.A.; Pourfayaz, F. Optimization of a grid-connected hybrid solar-wind-hydrogen CHP system for residential applications by efficient metaheuristic approaches. Appl. Therm. Eng. 2017, 123, 1263-1277. [CrossRef]

9. Dali, M.; Belhadj, J.; Roboam, X. Hybrid solar-wind system with battery storage operating in grid-connected and standalone mode: Control and energy management-Experimental investigation. Energy 2010, 35, 2587-2595. [CrossRef]

10. Mikati, M.; Santos, M.; Armenta-Deu, C. Electric grid dependence on the configuration of a small-scale wind and solar power hybrid system. Renew. Energy 2013, 57, 587-593. [CrossRef]

11. Zhang, D.; Liu, J.; Jiao, S.; Tian, H.; Lou, C.; Zhou, Z.; Zhang, J.; Wang, C.; Zuo, J. Research on the configuration and operation effect of the hybrid solar-wind-battery power generation system based on NSGA-II. Energy 2019, 189, 116121. [CrossRef]

12. Carpinelli, G.; Caramia, P.; Varilone, P. Multi-linear Monte Carlo simulation method for probabilistic load flow of distribution systems with wind and photovoltaic generation systems. Renew. Energy 2015, 76, 283-295. [CrossRef]

13. Duffie, J.A.; Beckman, W.A. Solar Engineering of Thermal Processes; Wiley: New York, NY, USA, 1980.

14. Ciocia, A.; Amato, A.; Di Leo, P.; Fichera, S.; Malgaroli, G.; Spertino, F.; Tzanova, S. Self-Consumption and Self-Sufficiency in Photovoltaic Systems: Effect of Grid Limitation and Storage Installation. Energies 2021, 14, 1591. [CrossRef]

15. Mavrigiannaki, A.; Gobakis, K.; Kolokotsa, D.; Kalaitzakis, K.; Pisello, A.L.; Piselli, C.; Laskari, M.; Saliari, M.; Assimakopoulos, M.-N.; Pignatta, G.; et al. Zero energy concept at neighborhood level: A case study analysis. Sol. Energy Adv. 2021, 1, 100002. [CrossRef]

16. Solar Panels. 2021. Available online: https:// www.europe-solarstore.com/solar-panels.html (accessed on 17 February 2022).

17. Sohani, A.; Naderi, S.; Torabi, F.; Sayyaadi, H.; Akhlaghi, Y.G.; Zhao, X.; Talukdar, K.; Said, Z. Application based multi-objective performance optimization of a proton exchange membrane fuel cell. J. Clean. Prod. 2020, 252, 119567. [CrossRef] 
18. D'Adamo, I.; de Monte, F.; Ferella, F.; Gastaldi, M. The case study of a photovoltaic plant located at the university of L'Aquila: An economic analysis. J. Clean. Prod. 2021, 278, 123561. [CrossRef]

19. Lal, R. Encyclopedia of Soil Science; CRC Press: Boca Raton, FL, USA, 2006.

20. Behbahaninia, A.; Banifateme, M.; Azmayesh, M.H.; Naderi, S.; Pignatta, G. Markov and Monte Carlo Simulation of Wasteto-Energy Power Plants Considering Variable Fuel Analysis and Failure Rates. J. Energy Resour. Technol. 2021, $144,062101$. [CrossRef]

21. Naderi, S.; Banifateme, M.; Pourali, O.; Behbahaninia, A.; MacGill, I.; Pignatta, G. Accurate capacity factor calculation of waste-to-energy power plants based on availability analysis and design/off-design performance. J. Clean. Prod. 2020, $275,123167$. [CrossRef]

22. List of Products by Manufacturer Braun. 2021. Available online: https://www.wattuneed.com/en/30_braun (accessed on 17 February 2022).

23. Sohani, A.; Naderi, S.; Torabi, F. Comprehensive comparative evaluation of different possible optimization scenarios for a polymer electrolyte membrane fuel cell. Energy Convers. Manag. 2019, 191, 247-260. [CrossRef] 